\title{
THE THIRD VIEW OF THE STATUS OF OUR NEW POSSESSIONS.
}

For the first time since the discussion as to the legal and constitutional status or Puerto Rico and the Philippines arose, a thoroughly intelligent and forceful argument has been advanced in favor of the "imperialist" contention. That argument is found in Mr. Abbott Lawrence Lowell's article on "The Status of Our New Possessions-A Third View," published in the November number of the Harvard Lazo Review. ${ }^{1}$

Mr. Lowell's view, briefly stated, is as follows: Neither the proposition that the power of Congress over the territories of the United States is absolutely unqualified by any constitutional restriction, nor the opposing doctrine that the limitations imposed by the United States Constitution upon the federal government apply wherever the jurisdiction of that government extends, harmonizes with commonly received opinion or accords with all the United States Court decisions, while the latter proposition is open to the further objection that it makes well nigh impossible the government of our new possessions properly acquired, and so may be called irrational. A third view is therefore necessitated, namely: "The theory, therefore, which best interprets the Constitution in the light of history, and which accords most completely with the authorities, would seem to be that territory may be so annexed as to make it a part of the United States, and that if so, all the general restrictions in the Constitution apply to it, save those on the organization of the judiciary; but that possessions may also be so acquired as not to form part of the United States, and in that case constitutional limitations, such as those requiring uniformity of taxation and trial by jury, do not apply." ${ }_{2}$ It is all a matter of treaty provision. In the case of Louisiana, Florida, California, the territory included in the Gadsen Purchase and Alaska, there were express treaty provisions giving to the inhabitants of the ceded territory, with the exception in the case of Alaska of the uncivilized native tribes, "the enjoyment of all the rights, advantages and immunities of the United States," and as respects all the territory of

\footnotetext{
1 I3 Harv. Law Rev. 155.
}

${ }^{2} 13$ Harv. Law Rev. 176. 
the United States ceded by treaties containing such express provisions the limitations imposed by the United States Constitution on the federal government have been held by "the overwhelming weight of judicial authority" to apply, and of course do apply. "But the recent treaty with Spain makes no such provision. It merely cedes Puerto Rico and the Philippines to this country without any stipulation in regard to the relation in which the islands or their inhabitants shall stand towards the United States. In fact, the ninth article-aiter providing that Spanish subjects, natives of the Peninsula and residing in the ceded territory, may preserve their allegiance to the Crown of Spain, or renounce it-substitutes for the clause in the earlier treaties, that in the latter case they shall acquire, or be admitted to the rights of citizens of the United States, the provision that they shall be held 'to have adopted the nationality of the territory in which they may reside;' and adds, 'The civil rights and political status of the native inhabitants of the territories hereby ceded to the United States shall be determined by the Congress.' Hence it is clear that if the government can acquire possessions without making them a part of the United States, it has done so in this case." 3 It can so acquire possessions. The authority showing that this is so, and that the limitations of the Federal Constitution do not apply in Puerto Rico and the Philippines, is meagre. but is found in a dictum of Mr. Justice Johnson in The American, etc., Ins. Co.'s v. 356 Bales of Cotton, I Peters 5 I 7 note, and in the cases of Fleming v. Page, 9 How. 603, and In Re Ross I40 L. S. 453 .

Mr. Lowell's doctrine outlined above has certain unsatisfactory features. The most striking is that he is loath to extend it as far as logically he ought to do. "It may well be," he remarks at the close of his article, "that some (constitutional) provisions have a universal bearing because they are in form restrictions upon the power of Congress rather than reservations of rights. Such are the provisions that no bill of attainder or ex post facto law shall be passed, that no title of nobility shall be granted, and that a regular statement and account of all public moneys shall be published from time to time. These rules stand upon a different footing from the rights guaranteed to the citizens, many of which are inapplicable except among a people whose social and political evolution has been consonant with our own." \& Such a position is logically indefensible. Every reservation or guarantee of rights in the Federal Constitution is in fact, if not in form, a restriction upon the power of Congress,

' I3 Harv. Law Rev. I71, I72.

' 13 Harv. Law Rev. I76. 
and in constitutional interpretation it is fact, not form that controls. When it is sought to relieve the legislation of Congress, applicable to any territory from constitutional restrictions, the only possible theory on which to do it is that the Constitution does not apply at all to such territory, unless Congress decrees that it shall. Ex post facto laws are no more forbidden by the Constitution than is lack of uniformity in taxation, and the right to the publication of regular statements and accounts of public moneys is no more guaranteed than is the right to trial by jury. Congress either has unlimited scope in dealing with the personal and property rights of Puerto Ricans and Filipinos in their respective islands, or its power is restricted by all the limitations provided in the Federal Constitution which are in terms of general application.

Mr. Lowell's argument against "the broader construction which extends the provisions of the Constitution over our new dependencies" is that it contradicts the authorities he cites, and besides "is irrational, because it extends the restrictions of the Constitution to conditions where they cannot be applied without rendering the government of our new dependencies well nigh impossible." "Surely," he adds, "no provision ought to be given an interpretation which leads to an irrational result, if the language will bear equally well a different construction." 5 In other words, he impliedly asserts that any construction of the Federal Constitution which makes that instrument forbid us to do what it may be expedient for us to do, or even what we want to do, is irrational and to be avoided. It is elementary, however, that the only reason for having prohibitions in the Federal Constitution is to prevent Congress from doing many things which might be expedient, or which Congress might and probably would want to do, and that in determining the constitutionality of any legislation questions of expediency or desirability are wholly irrelevant, except in the rare case where the uncertainty of the language used in the Constitution creates a genuine doubt as to its real meaning and application. The only thing for Congress or the court to do in a given case is to ascertain the true meaning and application of the Constitution and then see that full effect is given to all its provisions, whether they be positive or negative. Any other course of procedure would be wholly irrational in the real sense of the word.

Another unsatisfactory feature of Mr. Lowell's argument is that the authorities which he cites to support his contention are not only, as he admits, "meagre ;" they are not even at all in point.

'I3 Harv. Law Rev. 157. 
The opinion of Mr. Justice Johnson in Amer., etc., Ins. Co.'s v. Canter or 356 Bales of Cotton, I Peters 517 n., is pure obiter dicta to begin with, for on appeal from his decision in that case the United States Supreme Court expressly decided that the treaty with Spain, by its very terms, admitted the inhabitants of Florida to the enjoyment of the privileges, rights and immunities of the citizens of the United States, and that, therefore, "it is unnecessary to inquire whether this is not their condition independent of stipulation." * Moreover, Mr. Justice Johnson announced a doctrine which has since been repudiated by the United States Supreme Court, and which Mr. Lowell himself disowns. The original thirteen States, the Northwest territory, and future States to be admitted, are not the only ones entitled to the guarantees of the Federal Constitution, i. e., are not, as Mr. Justice Johnson said they were, "the sole objects of the Constitution; treaty provisions as well as Congressional legislation have given and can give newly acquired territories the benefit of those guarantees prior to Statehood.

In Fleming v. Page, 9. How. 603, the territory had not been and, in fact, never has been ceded to the United States by treaty; so the case could not be in point. The case of Fleming v. Page rightly holds that enemy's country which is occupied by Federal troops during a war, does not by virtue of that occupation become a part of the United States, even though under the rules of international law and comity, other nations must act as if it does; for the reason that every nation holds and acquires territory according to its own institutions and laws, that our relations with conquered territory do not depend upon the law of nations, but upon our own Constitution, and the acts of the proper authorities thereunder, that under our Constitution the power to enlarge the limits of the United States is not given to the President as military commander, but to the treaty making power, or the legislative authority, and that the limits of the United States cannot be enlarged, except by treaty or Congressional legislation. The Court was not con-

\footnotetext{
- 1 Peters 542.

'Taney, C. J., in delivering the opinion of the court, in Fleming v. Page, said: "The port of Tampico, at which the goods were shipped (to the United States) and the Mexican State of Tamaulipas, in which it is situated, were undoubtedly at the time of the shipment subject to the sovereignty and dominion of the United States. The Mexican authorities had been driven out or had submitted to our army and navy; and the country was in the exclusive and firm possession of the United States, and governed by its military authorities, acting under the orders of the President. But it does not follow that it was a part of the United States, or that it ceased to be a foreign country in the sense in which those words are used in the acts of Congress.
} 
cerned with a case where there was a treaty of cession, and it would clearly have made a difference, according to the principle enunciated in the opinion, if the sovereignty over Tampico had been ceded by a treaty. Apart from treaty or legislation. possessions acquired by conquest or cession do not become a part of the United States,

"The United States, it is true, may extend its boundaries by conquest or treaty, and may demand the cession of territory as the condition of peace, in order to indemnify its citizens for the injuries they have suffered, or to reimburse the government for the expenses of the war. But this can be done only by the treaty-makistg pozver or the legislative authority, and is not a part of the power conferrcd upon the President by the declaration of war. His duty and his power are purely military. * * * He may invade the hostile country and subject it to the sovereignty and authority of the United States. But his conquests do not enlarge the boundaries of this Union, nor extend the operation of our institutions and laws beyond the limits before assigned to them by the legislative power.

"It is true that when Tampico had been captured and the State of Tamaulipas subjugated, other nations were bound to regard the country, while our possession continued, as the territory of the United States, and to respect it as such. * * * As regarded all other nations it was a part of the United States, and belonged to them as exclusively as the territory included in our established boundaries.

"But y'et it was not a part of this Union. For every nation which acquires territory by treaty or conquest holds it according to its own institutions and laws. And the relation in which the port of Tampico stood to the United States, while it was occupied by their arms. did not depend upon the laws of nations, but upon our own Constitution and acts of Congress. The power of the President under which Tampico and the State- of Tamaulipas were conquered and held in subjection, was simply that of a military commander prosecuting a war waged against a public enemy by the authority of his government. * * * But the boundaries of the United States, as they existed when war was declared against Mexico, were not extended by the conquest; nor could they be regulated by the varying instances of war and be enlarged or diminished, as the armies on either side advanced or retreated. They remained unchanged. * * *

"And the constituted authorities to whom the power of making war and concluding peace is confided, and of determining whether a conquered country shall be permanently retained or not, neither claimed nor exercised any rights or powers in relation to the territory in question, but the rights of war. After it was subdued it was uniformly treated as an enemy's country and restored to the possession of the Mexican authorities when peace was concluded. And certainly its subjugation did not compel the United States, while they held it, to regard it as a part of their dominicns, nor to gize to it any form of civil government, nor to extend to it our laws. * * * Our oun Constitution and form of government must be our only guide. And we are entirely satisfied that under the Constitution and laws of the United States, Tampico was a foreign port within the meaning of the Act of 1846 , when these goods were shipped (from there to the United States), and that the cargos were liable to the duty charged upon them" (on their arrival at Philadelphia). 
but that is simply a reiteration of the general doctrine that property must be accepted to be acquired, and is but another way of saying that under our Constitution such acceptance is evidenced only when embodied in treaty or Congressional legislation. In Fleming v. Page there was neither, and the case is undoubtedly right.

The case of In Re Ross, I40 U. S. 453, presents a very different question. There we had a treaty, but it was a treaty which gave us permission to exercise certain rights in territory which was in no sense a part of the United States, and the Supreme Court of the United States expressly based the decision upon the ground that the Federal Constitution can have no operation in territory not owned by the United States. The language of the court in that case is as follows:

"By the Constitution, a government is ordained and established 'for the United States of America,' and not for countries outside of their limits. The guarantees it affords against accusation of capital or infamous crimes, except by indictment or presentment by a grand jury, and for an impartial trial by a jury when thus accused, apply only to citizens and others within the United States, or who are brought there for trial for alleged offenses committed elsewhere, and not to residents or temporary sojourners abroad. The Constitution can have no operation in another country."s

The case of In Re Ross is, of course, suggestive, as showing in the words of Mr. Lowell, that "although the legislative power of Congress might extend beyond the limits of the United States, the limitations imposed upon legislation for the benefit of individuals did not accompany and restrain it," but it attempts to conclude and does conclude nothing whatever about territory owned in full sovereignty by the United States.

But the most unsatisfactory feature of Mr. Lowell's argument is that he overlooks the fact, and all that it implies, that under the treaty with Spain the United States takes the entire and exclusive sovereignty over Puerto Rico and the Philippines. His argument assumes that because the treaty with Spain does not stipulate what the legal rights of the native inhabitants of the ceded islands shall be, but leaves "the civil rights and political status" of those inhabitants to be determined by Congress, therefore we have a situation essentially different from the conditions which hare heretofore confronted us under treaties ceding territory to the United States.

'I40 U. S., Field, J. (35 Lawyers' Coop. P. Co.'s Ed p. 586).

- i3 Harv. Law Rev. 175. 
The treaty, however, does not say that such civil rights and political status shall be determined by Congress unrestrained by any constitutional limitations, or that the ceded islands shall not be regarded as part of the United States, and in fact does not really seem to differ in any essential from the Hawaiian Joint Resolutions, which provide that the Hawaiian Islands "be and they are hereby annexed as a part of the territory of the United States," and which seem to Mr. Lowell to stand on the same footing as our earlier treaties. It is a great mistake to say that it is clear that if the government can acquire possessions without making them a part of the United States, it has done so in the case of Puerto Rico and the Philippines. The fact is that it has done so in the case of Cuba, but not in that of Puerto Rico or the Philippines. A glance at the treaty will make this clear. The following articles of the treaty and parts of articles bear directly on the question. ${ }^{10}$

"Article I. Cuba.

"Spain relinquishes all claim of sovereignty over and title to

"And as the island is, upon the evacuation by Spain, to be occupied by the United States, the United States will, so long as such occupation shall last, assume and discharge the obligations that may under international law result from the fact of its occupation, for the protection of life and property.

"ARTICLE II.

- "Spain cedes to the United States the island of Puerto Rico and other islands now under Spanish sovereignty in the West Indies, and the island of Guam in the Marianas or Ladrones.

"ARTICLE III.

"Spain cedes to the United States the archipelago known as the Philippine Islands. * * *

"The United States will pay to Spain the sum of twenty million dollars $(\$ 20,000,000)$ within three months after the exchange of the ratification of the present treaty.

"ArTicle VIII.

"In conformity with the provisions of Articles I, II and III of this treaty, Spain relinquishes in Cuba and cedes in Puerto Rico and other islands in the West Indies, in the island of Guam, and in the Philippine Archipelago, all the buildings, wharves, barracks,

${ }^{20} 30$ U. S. Stat. at Large, p. I755 ff. 
forts, structures, public highways, and other immovable property which in conformity with law belong to the public domain and as such belong to the Crown of Spain. ***

"In the aforesaid relinquishment or cession, as the case may be, are also included such rights as the Crown of Spain and its authorities possess in respect of the official archives and records, executive as well as judicial, in the islands above referred to which relate to said islands or the rights and property of their inhabitants. ***

"ARTICLE IX.

"Spanish subjects, natives of the Peninsula, residing in the territory over which Spain by the present treaty relinquishes or cedes her sovereignty, may remain in such territory or may remove therefrom * * * In case they remain in the territory, they may preserve their allegiance to the Crown of Spain by making before a court of record within a year from the date of exchange of ratification of this treaty a declaration of their decision to preserve such allegiance, in default of which declaration they shall be held to have adopted the nationality of the territory in which they may reside.

"The civil rights and political status of the native inhabitants of the territories hereby ceded to the United States shall be determined by the Congress.

\section{"ArTrcle XVI.}

"It is understood that any obligations assumed in this treaty by the United States with respect to Cuba are limited to the time of its occupancy thereof; but it will upon the termination of such occupancy, advise any government established in the island to assume the samre obligations."

It will be noticed that the important words in the foregoing are "relinquish" and "cede." Cuba is relinquished; Puerto Rico and the Philippines are ceded. The meaning of both words is plain. By having Spain simply relinquish Cuba, and by becoming ourselves responsible for the island as provided in the treaty, we aimed to make Cuba a sort of possession or charge without its becoming part of the United States, or entitled to the benefit of our Constitution or general laws; and by having Spain cede Puerto Rico and the Philippines we intended to change a military occupation into acquisition and to make the islands an integral part of the United States. Both objects seem to have been accomplished. There would seem to be no room to doubt that Cuba is in exactly the same legal situation with reference to our Constitution and laws as was the State of Tamaulipas in the case of Fleming v. Page, 
supra; and while the treaty merely says of Puerto Rico and the Philippines, that they, and all public property with them, are ceded to the United States, that would seem to make them a part of the United States, and thereby bound and privileged by its Constitution and general laws. In the words of Chief Justice Marshall :12

"The usage of the world is, if a nation be not entirely subdued, to consider the holding of conquered territory as a mere military occupation until its fate shall be determined at the treaty of peace. If it be ceded by the treaty, the acquisition is confirmed, and the ceded territory becosnes a part of the nation to which it is annexed; either on the terms stipulated in the treaty of cession or such as its new master shall impose. On such transfer of territory it has never been held that the relations of the inhabitants with each other undergo any change. Their relations with their former sovereign are dissolved ${ }^{12}$ and new relations are created between them and the government which has acquired their territory. The same act which transfers their country, transfers the allegiance of those who remain in it (in the absence of treaty stipulations to the contrary); and the law which may be denominated political is necessarily changed, although that which regulates the intercourse and general conduct of individuals remains in force until altered by the newly created power of the State."

By the phrase "the law which may be denominated political," Chief Justice Marshall, of course, meant to cover Constitutional law. Puerto Rico and the Philippines are as much a part of the United States and as much subject to and protected by the Federal Constitution as was the Louisiana purchase, or has been any other territorial acquisition in our past history.

It is, of course, quite conceivable that the United States may go a few steps farther than it has gone in the case of Cuba, and may some day, by treaty, acquire territory for a naval station, or for some other restricted purpose, or even for general purposes, and may in the treaty of cession provide that the ceded territory is not intended to be and shall not be regarded as a part of the United States, though subject to its full and exclusive sovereignty, that its inhabitants shall remain citizens of the ceding State, that neither they nor their descendants shall ever become citizens of the United States or entitled to any of the guarantees of the Federal Constitu-

\footnotetext{
"Amer., etc., Ins. Co.'s v. 356 Bales of Cotton, I 'Peters app. 542.

"Here the treaty has saved to Spain the allegiance of all "Spanish subjects, natives of the Peninsula," in ceded and relinquished territory, who within a fixed time make a prescribed declaration of their intention to preserve such allegiance.
} 
tion, unless otherwise specially provided by Congressional legislation, and then only as so specified; and it is quite conceivabie that such a treaty would be given effect to in all its provisions by the United States Supreme Court on the ground that such provisions are legitimately within the scope of the treaty making powers, and that such powers are, under the Constitution, of a higher grade than are the limitations of the Constitution. ${ }^{13}$ The real value of Mr. Lowell's article lies in the suggestion of such a possibility and of its reasonableness. But such a case is not the one we have under discussion. We are dealing simply with a case where the territory is ceded to the United States for all purposes for which the United States can receive it, and everything is left to Congress to regulate under its Constitutional powers, whatever they may be. Surely, then, there is no Constitutional reason for regarding Congress as having greater powers over such territory than it has been held to have over territory acquired under prior treaties, and we may confidently assert that it has no greater power. On principle and on authority, the provisions of the United States Constitution extend over Puerto Rico and the Philippines, and will so extend until we get rid of these islands.

1s "This Constitution and the laws of the United States, which shall be made in pursuance thereof, and all treaties made, or which shall be made under the authority of the United States, shall be the supreme iaw of the land." U. S. Const., Article IV.

George P. Costigax, Jr. 